\title{
Histological Seasonal Changes in Ovaries of Spotted Tinamous (Nothura maculosa Tinamidae, Temminck, 1815) Related to Gonadotrope Population
}

\author{
Cambios Histológicos Estacionales en Ovarios de Perdiz Común (Nothura maculosa Tinamidae, \\ Temminck, 1815) ) y su Relación con la Población de Gonadotropas \\ Juan Claver; Juan M. Rosa; Daniel M. Lombardo \& María C. Soñez
}

CLAVER, J.; ROSA, J. M.; LOMBARDO, D. M. \& SOÑEZ, M. C. Histological seasonal changes in ovaries of spotted tinamous (Nothura maculosa Tinamidae, Temminck, 1815) related to gonadotrope population. Int. J. Morphol., 26(2):353-361, 2008.

SUMMARY: Nothura maculosa is a South American Tinamidae with a marked seasonal reproductive pattern. This work describes ovarian seasonal changes in this species related to gonadotrope (GTHs) population. Ovary and pituitary samples were collected monthly from adult birds during four annual periods. They were fixed in Bouin's solution and processed for light microscopy. The data of post-fixation gonadal weight were analysed using STATISTIX 4.0. Histological sections of the ovaries were stained with H/E, PAS and Goldner-Masson trichrome. Single and double immunostaining were applied on pituitary sections with anti-chicken-FSH and anti-chickenLH antibodies. The samples were analysed in quarterly periods of the year, P1: March-May (resting stage); P2: June-August (developing stage); P3: September-November (reproductive stage); P4: December-February (involutive stage). Ovary weight (ow) significantly varied among periods $(\mathrm{p}<0.001)$. During $\mathrm{P} 1$, only primordial and previtellogenic follicles were observed, ow $0.09 \pm 0.01 \mathrm{~g}(\mathrm{n}=25)$; during P2, developing follicles with signs of vitellogenesis were detected, ow $0.13 \pm 0.01 \mathrm{~g}(\mathrm{n}=14)$; during P3, maximum follicular development was found, ow $0.9 \pm 0.15 \mathrm{~g}(\mathrm{n}=39)$; P4 exhibited great variability in follicular stages, ow $0.18 \pm 0.18 \mathrm{~g}(\mathrm{n}=19)$. Involutive atresia was observed in all the periods, while bursting atresia and post-ovulatory follicles were only characterized at P3 and P4. The GTHs containing few LH and FSH immunoreactive (ir) granules were predominant during P1-P2. The GTHs with LH ir granules were abundant in intermediate zone and caudal lobe in P3 and P4 while few cells contained both types of granules. The number of FSH cells was increased during P3 and P4. The histological ovarian changes were narrowly correlated with the variations in the gonadotrope population.

KEY WORDS: Birds; Gonadotropes; Nothura maculosa; Ovary; Pituitary; Reproduction; Tinamidae.

\section{INTRODUCTION}

The genus Nothura includes small Tinamidae species living in open areas of South America. Three species live in Argentina: Nothura maculosa (Temminck), Nothura darwini (Gray) and Nothura chacoensis (Conover) (Dabbene, 1972; del Hoyo \& Elliott, 1992). The spotted tinamou (Nothura maculosa) is the most widespread and abundant tinamou in Argentina with 6 sub-species described (Bump \& Bump, 1969; Del Hoyo \& Elliot) where is popular as a game bird enjoyed by hunters and appreciated for its delicious meat. Bump \& Bump have reported habitat characteristics, distribution and behaviour of this species in Argentina. As in all members of the family, incubation and chick care are carried out by the males (Handford \& Mares, 1985). With few exceptions, mating systems in tinamous are described as simultaneous polygyny for males and sequential polyandry for females (Handford \& Mares; Del Hoyo \& Elliot; Garitano-Zavala, 2003). In Nothura maculosa, mating systems are poorly known but it was suggested that may be monogamous at first but polygamous when older (Del Hoyo \& Elliot). Seasonal reproduction have been described in Nothura maculosa, with maximal (October) and minimal (April-May) periods of activity (Menegheti, 1981, 1984; Fleming Batalha da Silveira et al., 1981). Attempts were made to characterize stages of the annual cycle of these species based on the morphological changes in ovaries (Arriaga et al., 1983; Burger, 1991) and testes (Burger, 1992). 
Seasonal reproduction in birds is marked by activation of the hypothalamo-pituitary-gonadal axis (Leska \& Dusza., 2007). Adenohypophysis activity under hypothalamic control regulates annual cyclic changes in gonads (Benoit, 1962; Follett et al., 1966). Changes in cell pituitary populations of Nothura maculosa relative to the annual cycle have been previously determined (Soñez et al., 1995, 1997) but they were not correlated with ovarian histology. With the aim of better understanding reproductive parameters of this species, in this work we describe seasonal histological changes in ovaries correlated with immunocytochemical detection of gonadotropes during the annual cycle in a wild population of Nothura maculosa from Buenos Aires Province, Argentina.

\section{MATERIAL AND METHOD}

One hundred and twenty mature female Spotted tinamous were captured during four years, 5-20 animals monthly. The birds were maintained in cages 24 hours with food and water ad libitum. The population studied proceeded from San Miguel del Monte (35 $27^{\prime}$ ' S-Lat.- 58 48' WLength) and Florencio Varela (30 $50^{\circ}$ ' S-Lat.- $58^{\circ} 06^{\prime} \mathrm{W}$ Length) districts in Buenos Aires province. These zones are characterized by a temperate climate with mean temperatures $8-23{ }^{\circ} \mathrm{C}$ (winter-summer), annual rainy regime of $80 \mathrm{~mm}$ average, with $15 \mathrm{~L} / 9 \mathrm{D}$ daily photoperiod in summer and 9L/ $15 \mathrm{D}$ during winter.

The samples were analysed in four quarterly periods of the year: P1 (March-April-May), P2 (June-July-August), P3 (September-October-November) and P4 (DecemberJanuary-February).

Because age determination is not easy in this species, only females exceeding a weight of $200 \mathrm{~g}$ were considered mature according to published data (Bump \& Bump).

The animals were sacrificed by decapitation after chloroform inhalation. After macroscopic observations of the ovaries and follicles (number, colour and size), hypophysis, ovaries and oviducts were removed immediately, fixed in Bouin's solution for $3 \mathrm{~h}$ (hypophysis) and $24 \mathrm{~h}$ (ovaries and oviducts), dehydrated and embedded in Paraplast (Monoject Scientific, U.S.A.) for light microscopy. Gonads and oviducts were measured in fresh and ovaries were weighted after fixation. The oviducts length was considered as an additional parameter of the gonadal development. Ovary sections of 4-5 $\mu \mathrm{m}$ were stained with haematoxylin-eosin (H\&E), Goldner-Masson trichrome and periodic acid Schiff - haematoxylin (PAS/H). Weight data were statistically analysed by descriptive statistics, ANOVA,
post-ANOVA (Bonferroni test) and median test (non parametric) with significance of $0.05 \%$, using Statistics 4.0.

Immunocytochemical method (ICC). Pituitary serial sections were deparafinised, gradually hydrated in ethanol and washed in 0.5 M Tris saline buffer (TS), pH 7.6. An indirect ABC system (Vectastain Universal Elite ABC kit, PK-6200, Vector Labs.) was applied with polyclonal antibodies, anti-chicken FSH 1:500 and anti-chicken LH 1:2000, anti-turkey GH 1:1000 (kindly provided by J.A. Proudman, USDA-ARS Animal Hormone Program, USA) and monoclonal anti-chicken PRL 1:2000 (a gift from L.R. Berghman, Neuroendocrinology Lab., Zoological Institute, Leuven, Belgium). The endogenous peroxidase activity was inhibited using hydrogen peroxide $3 \%$. The sections previously treated with normal rabbit serum were incubated in a moist chamber at room temperature, for $30 \mathrm{~min}$ with the first specific antibody and the biotinilated second antibody. The immunocomplex was revealed by 3-3' diaminobenzidine (DAB, SIGMA), lightly counterstained with Mayer's haematoxylin, dehydrated, cleared and cover-slipped. Double immunostaining was carried out in some of the serial sections, washing with $\mathrm{TS}, \mathrm{pH} 7.6$ after the $\mathrm{DAB}$ reaction. The ICC procedure was repeated with the second specific antibody and biotinilated IgG. Incubation with alkaline phosphatase conjugated streptavidine (Label, Biogenex Labs.) was performed for $20 \mathrm{~min}$ at room temperature and revealed by $\mathrm{BCIP} / \mathrm{NBT}$ substrate solution (5-bromo, 4chloro, 3-indolyl phosphate nitroblue tetrazolium, Biogenex Labs.). Finally, the sections were counterstained, dehydrated, cleared and mounted.

In the adjacent serial sections of each slide, the first incubation with the specific antibody was omitted or replaced by pre-adsorbed antibody (working dilution of antibody with $7 \mathrm{mg} / \mathrm{ml}$ hormone, $24 \mathrm{~h}, 4^{\circ} \mathrm{C}$ ) performing the subsequent technique steps and substrate reactions described above for control staining.

\section{RESULTS}

Marked macroscopic differences in size and features were observed in gonads of each period (Fig 1). Also the oviduct length changed remarkably. During P1 and P2, the oviducts were scarcely developed and very thin; varying in length from 60 to $80 \mathrm{~mm}$. Their maximum development was observed in P3 with $170.28 \mathrm{~mm}$ average of length during October and November, while in September their features were similar to those in P2. They gradually decreased in length during P4 with $136.33 \mathrm{~mm}$ average in December, $35.65 \mathrm{~mm}$ average in January and similar to those in P1 during February. 


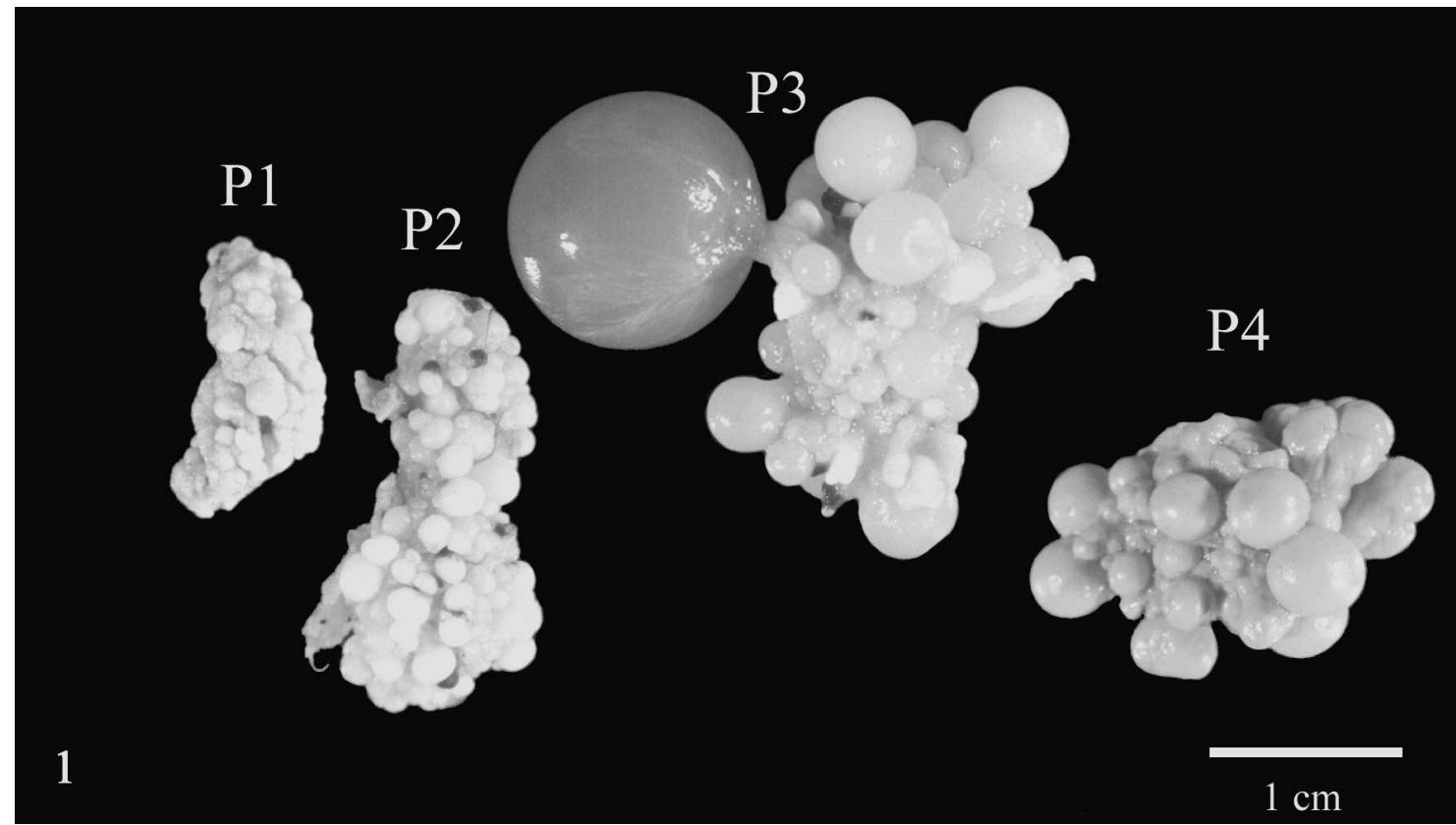

Fig. 1. Macroscopic view of ovaries in P1: resting stage; P2: developing stage; P3: reproductive stage; P4: involutive stage.

Significant differences in ovarian weight $(\mathrm{g})$ of the four periods were found ( $\mathrm{p}<0.001$ ); P1: 0.09 \pm 0.01 (mean \pm SEM) ( $n=25), P 2: 0.13 \pm 0.01(n=14) ; P 3: 0.90 \pm 0.15(n=39)$; P4: $0.18 \pm 0.18(n=19)$.

The ovaries were covered by single columnar epithelium, containing many follicles in the cortical zone. The type and degree of development varied between the stages. The inner medullar stroma was composed of well vascularised and innervated connective tissue, with spaces (lacunae) whose covering epithelium changed in each period. Pituitary pars distalis in Nothura consisted of two lobes, which were only identifiable by their cellular distribution. By the localization of anti-tGH, anti-chPRL positive cells, previously reported (Soñez et al., 1995), the caudal and cephalic lobes can be distinguished respectively, and also LH and FSH gonadotropes were localized.

\section{P1: Resting stage (March, April, May).}

The ovaries. Ovaries in this period were ovoid, whitish, with granular surface (Fig. 1), measuring in average $11.75 \mathrm{~mm}$ length and weighting $0.09 \mathrm{~g}$ post fixed (Tables I, II), with slightly protruding follicles of 1 to $2.5 \mathrm{~mm}$ in diameter or smaller. Primordial and early growing follicles (previtellogenic) were predominant (Fig. 6), 120 to $200 \mathrm{~mm}$ in diameter, and peripherally located. Oocytes of primordial follicles were enclosed by simple cubic epithelium (pregranulosa cells), showing eccentric nuclei and acidophilic cytoplasm containing small vacuoles in the peripheral region of the ooplasm. Some spindle shaped cells surrounded the pregranulosa basal membrane. Previtellogenic follicles were characterized by larger oocyte without granulosa changes in comparison with primordial ones and the thecal layer was well defined, composed by fusiform cells. Occasionally, vitellogenic follicles were found. The medulla was integrated by a net of connective tissue and smooth muscle. Single squamous epithelium bound large collapsed lacunae. Arterioles with thick medium layer were abundant in the medulla (Fig. 5).

Gonadotrope population. Few and small gonadotrope cells were observed, whose scarce cytoplasm contained evident immunoreactive (ir) granules. The spherical and large

Table I. Descriptive statistics of ovaries lenght (mm) in each period of Nothura maculosa annual cycle.

\begin{tabular}{ccccccc}
\hline PERIOD & $\mathbf{N}$ & MEDIAN & MEAN & SE & MIN & MAX \\
$\mathbf{1}$ & 16 & 12.5 & 11.75 & 2.67 & 7 & 15 \\
$\mathbf{2}$ & 11 & 12 & 12.88 & 2.63 & 10 & 18 \\
$\mathbf{3}$ & 15 & 19 & 19.27 & 9.09 & 12 & 50 \\
$\mathbf{4}$ & 15 & 14 & 14.81 & 7.06 & 8 & 28 \\
\hline
\end{tabular}


CLAVER, J.; ROSA; J. M.; LOMBARDO, D. M. \& SOÑEZ, M. C. Histological seasonal changes in ovaries of spotted tinamous (Nothura maculosa Tinamidae, Temminck, 1815) related to gonadotrope population. Int. J. Morphol., 26(2):353-361, 2008.

Table II. Descriptive statistics of postfixed ovary weight (g) in each period of Nothura maculosa annual cycle.

\begin{tabular}{ccccccc}
\hline PERIOD & $\mathbf{N}$ & MEDIAN & MEAN & SE & MIN & MAX \\
$\mathbf{1}$ & 25 & 0.09 & 0.09 & 0.01 & 0.02 & 0.31 \\
$\mathbf{2}$ & 14 & 0.14 & 0.12 & 0.02 & 0.07 & 0.32 \\
$\mathbf{3}$ & 39 & 0.90 & 0.54 & 0.15 & 0.09 & 3.72 \\
$\mathbf{4}$ & 19 & 0.69 & 0.19 & 0.28 & 0.04 & 5.33 \\
\hline
\end{tabular}

nucleus showed loose chromatin with 1 or 2 nucleoli. The FSH-tropes were centrally located in the gland while the LH-tropes were distributed in both lobes, isolated or in groups of two ir cells (Figs. 3 and 4).

\section{P2: Maturing stage (June, July, August)}

The ovaries. Ovaries in this period showed more irregular surface than those of P1 (Fig. 1), measuring in average 12.88 mm length and $0.12 \mathrm{~g}$. postfixed weight (Tables I and II). Most of them were whitish while some yellowish ones (vitellogenic) were observed in August. The largest follicles, 2 to $4 \mathrm{~mm}$ in diameter, were located near the ovarian epithelium (Fig. 9). Numerous vitellogenic follicles contained oocytes with eccentric nucleus, condensed chromatin and peripherally vacuolated cytoplasm. The granulosa was composed by cubic epithelium with a remarkable PAS (+) basal membrane. Theca layers were well developed. Empty interstitial lacunae were covered by single squamous epithelium but stratified epithelium with large vacuolated cells was seen in some cases (Fig. 10).
Gonadotrope population. Gonadotropes were enlarged in size, containing more abundant ir granules than cells of P1. FSH-tropes were characteristically arranged in cords, polarized and distributed in the caudal lobe, with some of them in the intermediate zone (Fig. 7). LH-tropes showed features similar to those of P1 cells. Few peripheral cells showed $i r$ granules for both antibodies (Fig. 8).

\section{P3: Reproductive stage (September, October, November)}

The ovaries. Ovaries in this period increased notably in volume and showed the most irregular surface in comparison with the other periods (Fig. 1), measuring in average $19.27 \mathrm{~mm}$ length and $0.54 \mathrm{~g}$. postfixed weight (Tables I and II). Larger spherical and orange follicles of $22 \mathrm{~mm}$ in maximum diameter (pre-ovulatory follicles) were connected by a long pedicle to the ovary and also other irregular pediculate structures were observed. Numerous vacuoles were observed centrally in the oocyte and PAS (+) granules appeared in the cortical region (Fig. 13). The

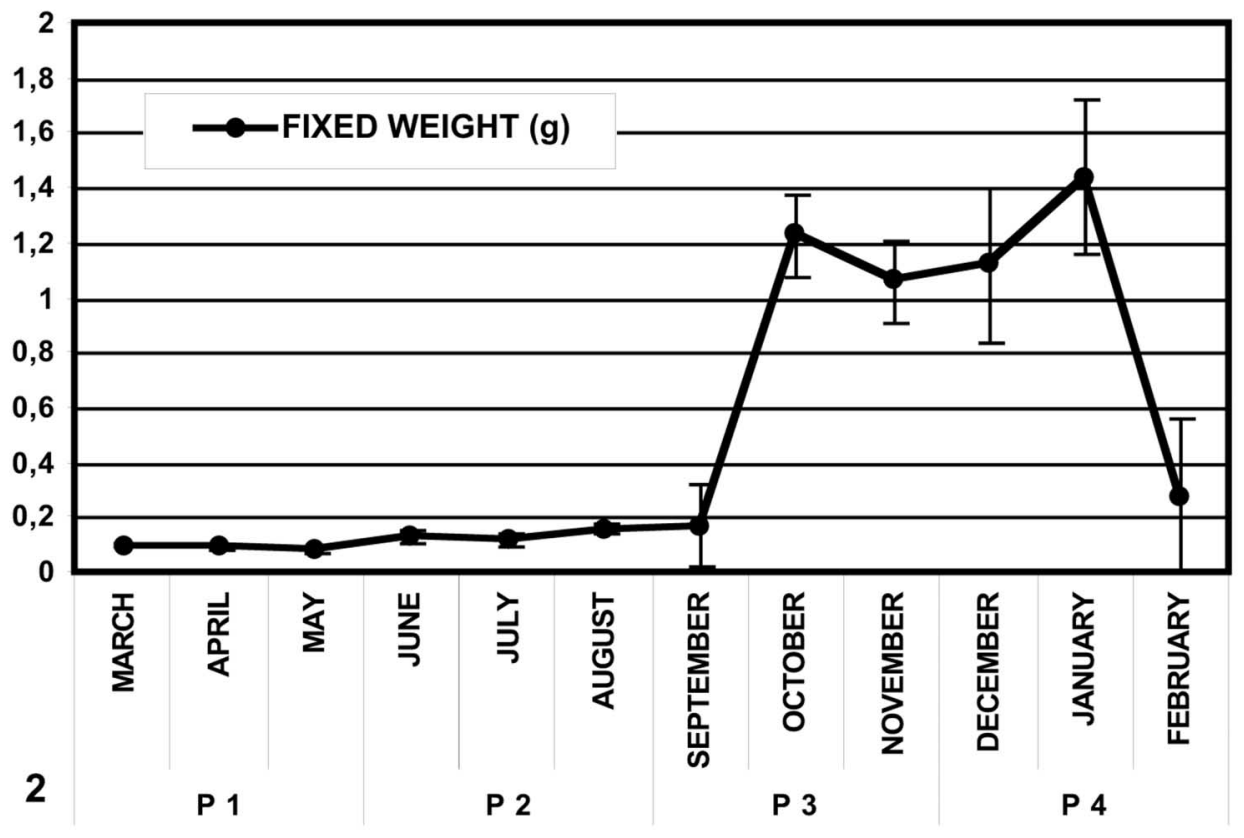

Fig. 2. Monthly changes of fixed ovary weight during four annual cycles (mean \pm SEM). SEM in P1 and P2 were 0.01 and 0.02 , respectively. 
zona radiata, a peripheral region of the oocyte with fine cytoplasmic processes, and the perivitelline layer were well defined (Fig. 13). The granulosa was composed of a pseudostratified columnar epithelium with strong PAS (+) basal membrane. The theca was a vascular sheath of cellular connective tissue with some isolate theca gland cells, permeated with large and irregular capillaries. The first sign of non-bursting atresia, in primordial and growing follicles, was shrinkage, while the lipid bodies coalesced to form acidophilic masses in the ooplasm. Few large follicles showed features of bursting atresia, characterized by follicular wall break and vitellium escaping into the neighbouring lacunae (Fig. 14), and inside lacunae epithelial cells. Many of these atretic follicles presented follicular wall projections crossing the center, showing a central axis of dense connective tissue and covered by thecal and hypertrophied granulosa cells. Post ovulatory follicles were frequently found in P3 and P4 (Fig. 18) and were located near the gonad surface. Their hypertrophied and vacuolated cells filled the space occupied by the ovulated oocyte and surrounded by thick layer of small, acidophilic cells. Condensed connective tissue bounded this structure.

Gonadotrope population. The ir granules storage was increased in gonadotropes which were more voluminous than P1 and P2, and were observed in both lobes of the gland. FSH tropes were arranged in the characteristic cords in the caudal lobe and in groups of 3 to 4 ir cells or isolated in the cephalic lobe (Fig. 11), while LH tropes were also seen as isolated or in small groups of 3 to 4 cells (Fig.12).

\section{P4: Involutive stage (December, January, February)}

The ovaries. The ovaries measured in average $14.81 \mathrm{~mm}$ length and $0.19 \mathrm{~g}$ post fixed weight (Tables 1,2$)$. Some of them showed similar active signs as in P3 with predominant large orange follicles while others were in clear regression with whitish follicles. Atretic and post ovulatory follicles were frequently observed. Interstitial lacunae were filled with vitelline and surrounded by phagocytic epithelial cells (Fig. 17). The late stages of regression of postovulatory follicle and atresia were difficult to distinguish due to the fibrosis of the theca.

Gonadotrope population. Gonadotropes showed similar features to those in P3. They were numerous and distributed in the entire gland. FSH tropes were arranged in cords and LH tropes were isolated or formed groups of scarce cells (Fig 15). Double immunostaining allowed distinguishing cells containing only FSH $(+)$ granules at the periphery and $\mathrm{LH}(+)$ cells in the middle of the gland. Cells containing positive granules for both antibodies were located among them (Fig. 16).

\section{DISCUSSION}

Although most histological features observed in Nothura maculosa ovaries were similar to those of domestic and wild avian species (Hodges 1974; Johnson, 2000; Jones, 1978; Kern, 1972) they showed some specific characteristics. The two types of atresia, non-bursting atresia (Type 1) and bursting atresia (Type 2), described in the ovary of the domestic hen and white-crowned sparrow (Gupta et al., 1988; Kern), were seen in small and larger follicles of Nothura maculosa, respectively. Changes in non-bursting atresia of this species were similar to those reported in Columba livia and Gallus domesticus by Guraya (1976). Bursting atresia was described previously in Nothura maculosa (Arriaga et al.) in october ovaries. Internal follicular wall projections that we observed in bursting atresia of Nothura have not been described in other avian species. Bursting atresia in hens occurs at the end of the egg-laying period (Nili \& Kelly, 1996). Bump \& Bump reported the possibility of more than one egg-laying period in Nothura maculosa, but we have not seen the remarkable regression among periods reported by the authors. Probably the frequency of bursting atresia that we have observed in Nothura maculosa during P3 and P4 may indicate more than one egg-laying periods.

Atretic vitellogenic follicles finally disappeared from the ovary of Nothura maculosa without making a visible contribution to the stroma. So during P1 the ovarian stroma did not show any lipidic cells such as interstitial gland-cells which have been reported in domestic species (Gupta et al.; Guraya; Hodges and Kern). The large stromal spaces (lacunae) boundered by a phagocytic epithelium and containing erythrocytes, yolk and the ooplasm of ruptured follicles initially observed in hens by Callebaut (1979) was described by Arriaga et al. in Nothura maculosa as stromal spaces. Similar structures were described in White crowned Sparrow's ovary during spring and the breeding period, disappearing in July (Kern). We also found lacunar spaces in Nothura maculosa ovaries of P3 and P4. During P1, these spaces did not disappear but they were emptied. Transformation of lacuna-lining cells into phagocytic cells occurred in the ovary of laying hens after bursting atresia and exposure of these cells to released yolk (Nili \& Kelly). In contrast, we observed that this transformation occurred in Nothura maculosa before bursting atresia. So in this species the presence of yolk in the lacunae spaces seems not to be the cause of transformation of this lining epithelium. Yolk vacuoles in the cytoplasm of these cells may indicate that they were phagocytically active when the yolk was released to the stroma. Largest follicles presented a perivitelline 

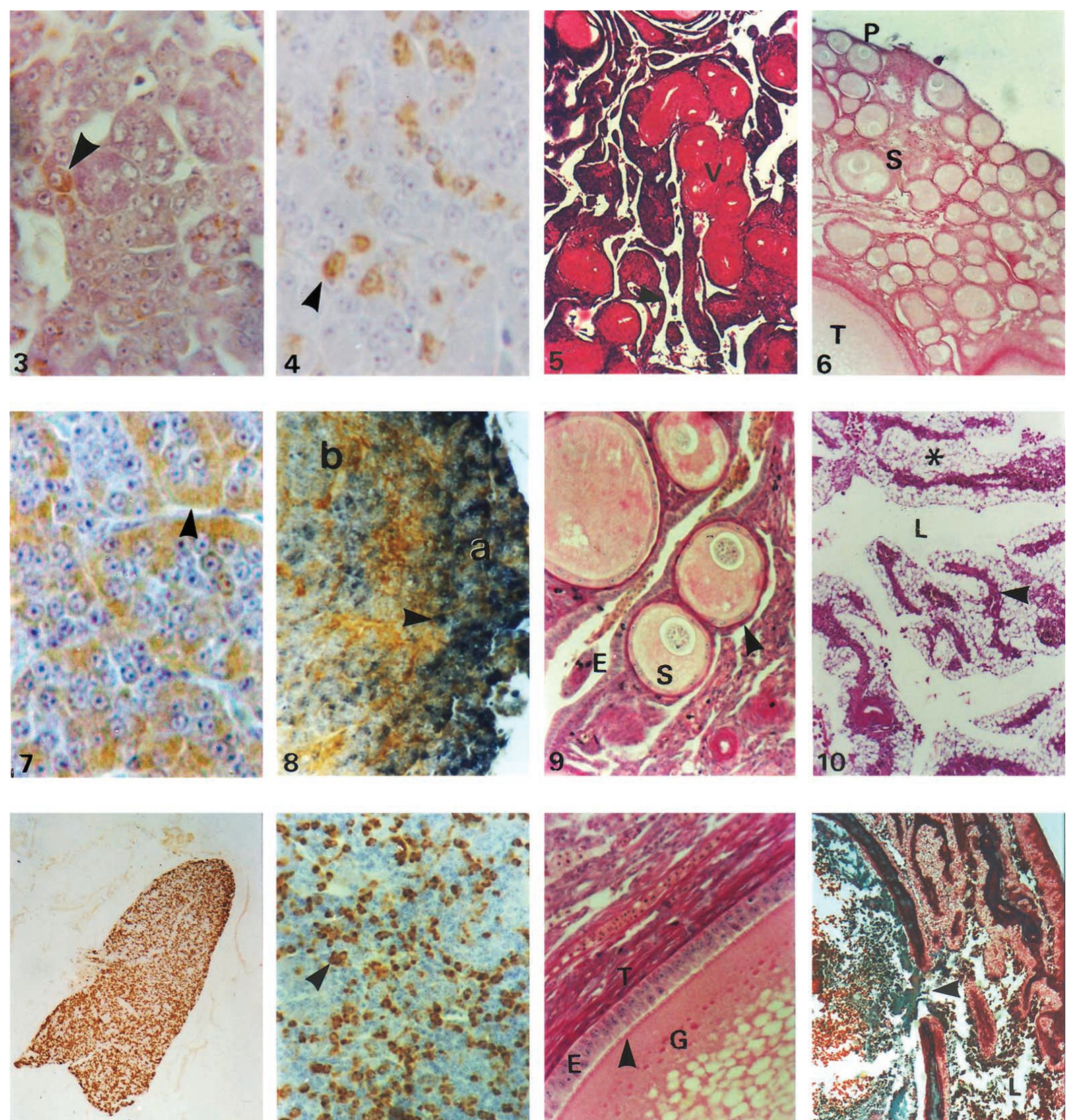

11
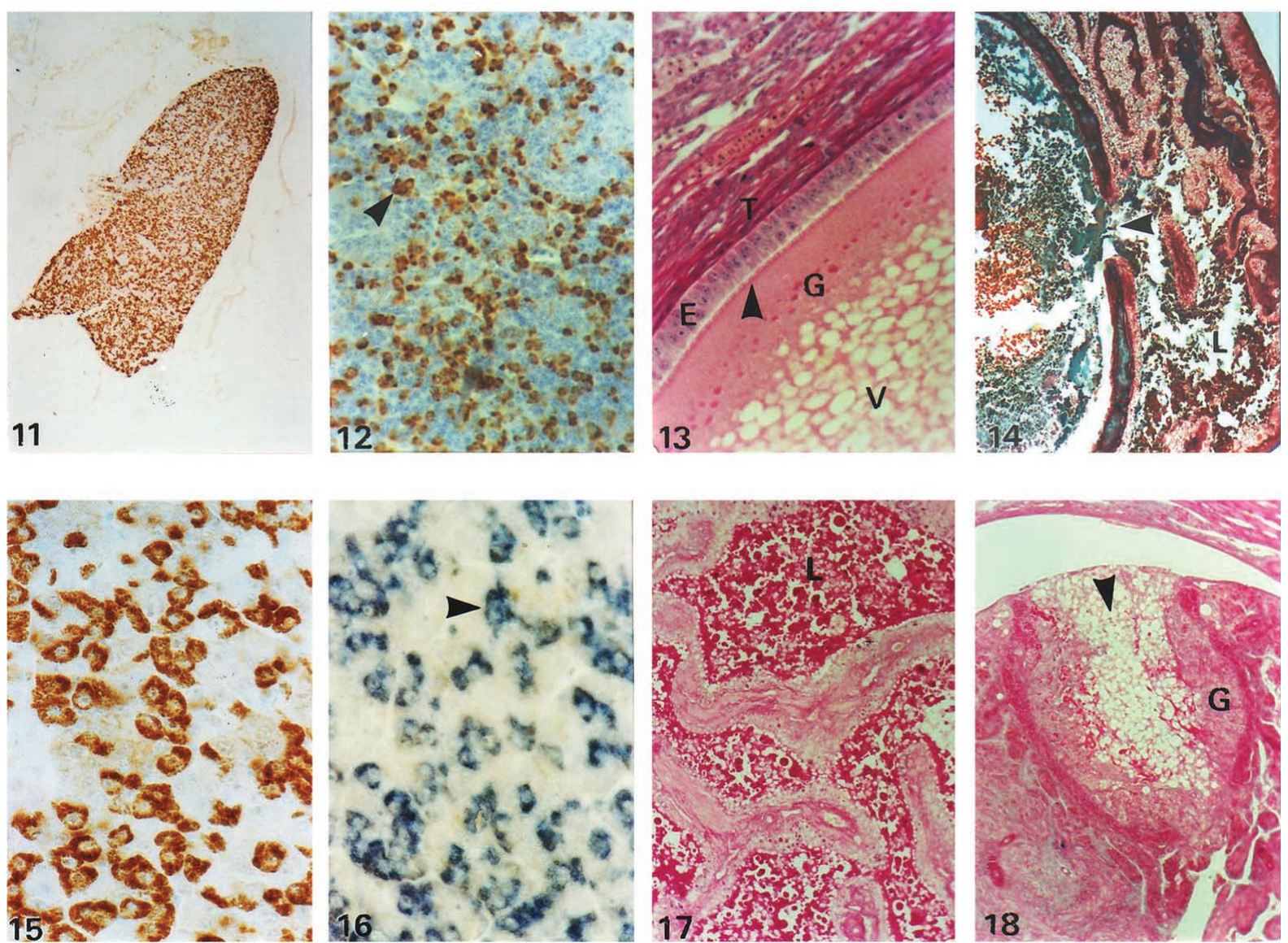
Fig. 3. Anti-chicken FSH antibody positive cells in cephalic lobe of pituitary gland during P1 (arrow head) isolated and scarcely distributed. Counterstained with haematoxylin (H). X330.

Fig. 4. Anti-chicken LH antibody positive cells in caudal lobe of pituitary gland during P1 (arrow head), isolated and more abundant in comparison with anti-chicken FSH positive cells. Counterstained with haematoxylin (H). X132.

Fig. 5. Ovary stroma during P1 showing empty interstitial lacunae (arrow head) and abundant vascularisation (V). H/E. X33.

Fig. 6. Ovary cortex during P1 showing abundant primordial follicles (P), some secondary follicles (S) and few tertiary follicles (T). H/E. X33. Fig. 7. Anti-chicken FSH positive cells only in caudal lobe of pituitary gland during P2. The FSH-tropes were arranged in cords (arrow head). Counterstained with haematoxylin (H). X132.

Fig. 8. Double immunocytochemical staining using anti-chicken FSH and LH serum. Blue cells were FSH positive peripherally located (a) while brown LH-positive cells (b) were found in all the gland and few cells containing both positive granules (arrow head) were observed. Counterstained with haematoxylin (H). X132.

Fig. 9. Ovary cortex during P2 showing secondary follicles (S) near the ovary epithelium (E). Thecal layer is strongly PAS positive (arrow head). PAS / H. X132.

Fig. 10. Interstitial stroma with dilated lacunae (L) covered by numerous vacuolated cells (*). Connective tissue (arrow head). PAS / H. X132. Fig. 11. Sagittal section of pituitary gland during P3 showing anti-ch FSH positive cells found in both lobes. Counterstained with haematoxylin $(\mathrm{H}) . \mathrm{X} 13$.

Fig. 12. Anti-chicken LH positive cells among the lobes of pituitary gland during P3 $(\neq)$. They were isolated. Counterstained with haematoxylin (H). X132.

Fig. 13. Vitellogenic follicle in ovary of P3. There are PAS positive thecal layers (T). The granulosa ephytelium (E) is seudostratified. In oocyte: the radiata zone (arrow ahead), yolk granules (G) and the vacuolated cytoplasm (V). PAS / H. X132.

Fig. 14. Bursting atretia in ovary of P3. Follicular wall is broken (arrow head), interstitial lacunae contain vitellium granules (L). GoldnerMasson trichrome. X33.

Fig. 15. FSH-tropes in caudal lobe of pituitary gland during P4. They contain abundant granules (arrow head). Counterstained with haematoxylin (H). X330.

Fig. 16. Double immunocytochemical staining using anti-chicken FSH and LH serum in pituitary gland during P4. Some cells contain both types of granules (Blue: anti-cFSH, brown: anti-cLH) (arrow head). Counterstained with haematoxylin (H). X330.

Fig. 17. Interstitial lacunae containing PAS positive vitellium granules (L) in ovary during P4. PAS / H. X132.

Fig. 18. Post-ovulatory follicle in ovary during P4. The granulosa layer is hypertrophic $(\mathrm{G})$ with central cells vacuolated ( $\neq)$. PAS / H. X33.

membrane, similar to that described in laying hens by Waclawek et al. (1998).

The distribution of gonadotropes in the pituitary gland and their morphological changes would be correlated to gonadotrophin secretion and seasonal ovarian changes. Separate LH and FSH positives cells were almost exclusively found in accordance with the findings in chicken pituitary (Proudman et al., 1999). However, the dual-label staining revealed cells containing both types of granules near the periphery of the gland and their distribution was different. LH-tropes were distributed throughout the anterior pituitary during all the annual cycle but FSH-tropes were not found in the cephalic lobe of P1 and P2, while they were localized throughout the gland in P3 and P4. Both cell types changed in number and in the storage in granules which increased in P3 and P4 in agreement with previous ultrastructural observations. (Soñez et al., 1997).

The annual reproductive cycle reported in Nothura maculosa of South Eastern Brazil (Burger) shows similar patterns in ovarian and oviductal development and involution compared with our results.
In conclusion, Nothura maculosa ovaries showed clear seasonal changes of growth and regression correlated with changes in gonadotrope population. During P1 the ovaries were clearly in the resting stage and there were few and small gonadotropes. Histological changes gradually appeared in ovaries and the gonadotrope population of P2. Follicular growth began at the end of P2 in relation with FSH-trope increase. Maximum ovary and gonadotrope development was reached during P3. P4 was the period when most ovarian variability appeared without changes in gonadotrope population.

The present study provides a basis for a thorough investigation on the reproduction of this species.

\section{ACKNOWLEDGMENTS}

We thank Dr. J. A. Proudman at USDA - ARS Maryland for the gift of anti-chicken FSH-LH sera. We are very gratefully to Dr. Irene Von Lawzewitch for her support to complete this work. 
CLAVER, J.; ROSA, J. M.; LOMBARDO, D. M. \& SOÑEZ, M. C. Cambios histológicos estacionales en ovarios de perdiz (Nothura maculosa Tinamidae, Temminck, 1815) y su relación con la población de gonadotropas. Int. J. Morphol., 26(2):353-361, 2008.

RESUMEN: Nothura maculosa es un tinámido sudamericano que presenta marcada estacionalidad reproductiva. Este trabajo describe los cambios estacionales del ovario de esta especie, en relación con la población de gonadotropas (GTHs). Muestras de ovarios y pituitarias de ejemplares adultos fueron colectadas mensualmente durante cuatro años; se fijaron en solución de Bouin y procesadas para M.O. Los datos del peso gonadal posfijación fueron analizados usando STATISTIX 4.0. Los cortes de ovarios fueron coloreados con H/E, P.A.S. y Tricrómico de Goldner-Masson. En cortes de adenohipófisis se aplicó inmunocitoquímica simple y doble (sistema ABC, Vector Lab.), empleando anticuerpos anti-pollo FSH y anti-pollo LH. Las muestras se analizaron en períodos trimestrales de cada año (P): P1: Marzo-Abril-Mayo (etapa de reposo), P2: Junio-Julio-Agosto (etapa de desarrollo), P3: Septiembre-Octubre-Noviembre (etapa reproductiva), P4: Diciembre-Enero-Febrero (etapa involutiva). El peso de los ovarios (PO) varió significativamente entre los periodos ( $\mathrm{p}<0.001)$. Durante P1, sólo se observaron folículos primordiales y pre-vitelogénicos, PO 0.09 $\pm 0.01 \mathrm{~g}$ ( $\mathrm{n}=25$ ); durante P2, se detectaron folículos en desarrollo con signos de vitelogénesis, PO $0.13 \pm 0.01 \mathrm{~g}(\mathrm{n}=14)$; durante P3, se encontró máximo desarrollo folicular, PO $0.90 \pm 0.15 \mathrm{~g}(\mathrm{n}=39)$; P4 exhibió gran variabilidad folicular, PO $0.18 \pm 0.18 \mathrm{~g}(\mathrm{n}=19)$. La atresia involutiva se observó en todos los períodos, mientras que la atresia explosiva y los folículos postovulatorios caracterizaron a P3 y P4. Las GTHs conteniendo escasos gránulos LH y FSH inmunoreactivos (ir) predominaron durante P1 y P2. Las GTHs con gránulos LHir eran abundantes en la zona intermedia y en el lóbulo caudal en P3 y P4 mientras que escasas células contenían ambos tipos de gránulos. El número de células FSHir se incrementó durante P3 y P4. Los cambios histológicos del ovario se correlacionaron estrechamente con las variaciones en la población de gonadotropas.

PALABRAS CLAVE: Aves; Gonadotropas; Nothura maculosa; Ovario; Pituitaria; Reproducción; Tinamidae.

\section{REFERENCES}

Arriaga, A.; Nicora, O. \& Ibañez, N. Variaciones estacionales en ovario de inambu chico comun (Nothura maculosa). El Hornero $N^{o}$ extr.: 14-27, 1983.

Benoit, J. Hypothalamo-hypophyseal control of the sexual activity in birds. Gen Comp Endocrinol 1:254-74, 1962.

Bump, G.; Bump, J.W. A study of the spotted tinamous and the pale spotted tinamous of Argentina. Spec. Sci. Rep. US Fish Wildl Serv., 120:1-160, 1969.

Burger, M. I. Ciclo reproductivo de fêmeas de uma população de Nothura maculosa TEMMINK, 1815 (Aves,Tinamidae) no Rio Grande de Sul, Brasil. Iheringia, Sér Zool. 71:161-74, 1991.

Burger, M.I. Ciclo reprodutivo de machos de uma populaçâo de Nothura maculosa TEMMINCK, 1815 (Aves, Tinamidae) no Rio Grande Do Sul, Brasil. Iheringia, Sér. Zool., 73:77-90, 1992.

Callebaut, M. The avian ovary is an open organ. Anat. Embryol., 158:103-19, 1979.

Dabbene, R. Los tinamidos o perdices de la Argentina. In Aves de caza de la República Argentina. Ed. Albatros, Buenos Aires, 1972. pp 85-113.

Del Hoyo, J. \& Elliott, A. eds Order Tinamiformes. In "Handbook of the birds of the world" Ed by Lynx,
Barcelona, Spain, 1992. V. I. pp 111-38.

Fleming Batalha da Silveira, C. \& Menegheti, J.O. Estudo sobre a relaçâo peso e sexo em Nothura maculosa (TEMMINCK,1815) (Aves, Tinamiformes, Tinamidae). Iheringia, Sér Zool., 58:7-16, 1981.

Follett, B. K. \& Farner, D.S. Pituitary gonadotropins in the Japanese Quail (Coturnix japonica) during photoperiodically induced gonadal growth. Gen. Comp. Endocrinol., 7:125-31, 1966.

Garitano-Zavala, A: Proyectos demostrativos de crianza de pisacca (Nothoprocta ornata) en Bolivia. Informe del Instituto de Ecología, Universidad Mayor de San Andrés. Fundación para el Desarrollo de la Ecología. La Paz, Bolivia, 2003.

Gupta, S. K.; Gilbert, A. B. \& Walker, M.A. Histological study of follicular atresia in the ovary of the domestic hen (Gallus domesticus). J. Reprod. Fert., 82:219-25, 1988.

Guraya, S.S. Morphological and histochemical observations on follicular atresia and interstitial gland tissue in the columbid ovary. Gen. Comp. Endocrinol., 30:534-8, 1976.

Handford, P. \& Mares, M. A. The mating systems of ratites and tinamous. An evolutionary perspective. Biol. J. Linn. Soc., 25:77-104, 1985. 
CLAVER, J.; ROSA; J. M.; LOMBARDO, D. M. \& SOÑEZ, M. C. Histological seasonal changes in ovaries of spotted tinamous (Nothura maculosa Tinamidae, Temminck, 1815) related to gonadotrope population. Int. J. Morphol., 26(2):353-361, 2008.

Hodges, R. D. The histology of the Fowl. Academic Press. Inc., London, 1974.

Johnson, A. L. Reproduction in female. In "Sturkie's Avian Physiology" Ed by G. Causey Whiton. Acadeemic Press, 2000. pp. 569-96.

Jones, R. E. The vertebrate ovary. Comparative biology and evolution. Plenum press, New York and London, 1978.

Kern, M. D. Seasonal changes in the reproductive system of the female White-crowned sparrow, Zonotrichia gambelii, in captivity and in the field. Z. Zellforsch., 126:297-319, 1972.

Leska, A. \& Dusza, L. Seasonal changes in the hypothalamopituitary-gonadal axis in birds. Reproductive Biology., 7(2): 99-126, 2007.

Menegheti, J. O. Acasalamento em Nothura maculosa (Temminck,1815) (Tinamidae) duraçâo, período, magnitude e sua variaçâo. Iheringia Sér. Zool., 64:3-14, 1984.

Menegheti, J.O. Observações preliminares sobre o acasalamento e recrutamento em Nothura maculosa (Temminck, 1815) (Aves Tinamidae) no Rio Grande do Sul, Brasil. Iheringia Sér. Zool., 59:65-75, 1981.

Nili, H. \& Kelly, W.R. Form and function of lacunae in the ovary of the laying hen. Anat. Rec., 244:165-74, 1996.

Proudman, J.A.; Vandesande, F. \& Berghman, L.R. Immunochemical evidence that follicle-stimulating hormone and luteinizing hormone reside in separate cells in the chicken pituitary. Biol. Reprod., 60:1324-8, 1999.

Soñez, M.C.; Stancato, M.R. \& Von Lawzewitsch, I. Immunocytochemical identification of prolactin and somatotropin-containing cells in adenohypophysis of Nothura maculosa (Tinamidae. Temminck, 1815) during recess and active reproduction periods using human hormone antisera. Com. Biol., 13:85-100, 1995.

Soñez, M.C. \& Von Lawzewitsch, I. Ultrastructural identification of pituitary cells in Nothura maculosa (Tinamidae. Temminck, 1815). Biocell, 21:103-14, 1997.

Waclawek, M,; Foisner, R.; Nimpf, J. \& Schneider, W. J. The chicken homologue of zona pellucida protein-3 is synthesized by granulose cells. Biol. Reprod., 59:12309, 1998.
Correspondence to:

Dr. Juan Claver

Histología y Embriología

Facultad de Ciencias Veterinarias

Universidad de Buenos Aires

Chorroarin 280

C1427CWO

Buenos Aires

ARGENTINA

Tel.: 54-011-4524-8458

Fax.: 54-011-4524-8480

Email: jclaver@fvet.uba.ar mcsonez@fvet.uba.ar

Received: 14-02-2008

Accepted: 22-03-2008 
